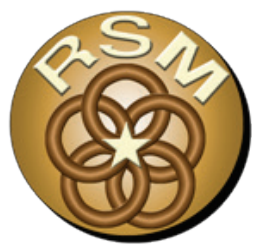

\title{
Feasibility of Nearshore Placement Near the Swinomish Navigation Channel; Puget Sound, Washington
}

\author{
by David R. Michalsen and Scott H. Brown
}

PURPOSE: This Regional Sediment Management Technical Note (RSM-TN) discusses the analysis performed to investigate the feasibility of dredged material beneficial use sites (BUS) located in the nearshore region in Skagit Bay, Puget Sound, Washington. The Swinomish Channel, located adjacent to the North Fork Skagit River, presently has only two deep water placement sites available to accept U.S. Army Corps of Engineers (USACE) Operations and Maintenance (O\&M) related dredged material. As part of the RSM initiative, the investigation sought to identify a low-cost, technically feasible, and environmentally acceptable alternative for future dredging and placement operations over the project life cycle. In this study, a threedimensional (3-D) hydrodynamic circulation model and a Lagrangian-based Particle Tracking Model (PTM) were employed to investigate the fate and transport of dredged material placed in the vicinity of the project site. The modeling serves as a basis to support new National Environmental Policy Act documentation for the USACE O\&M dredging project over the next 13 years.

BACKGROUND: Annually, the Skagit River supplies approximately 2.8 million tons of sediment into Skagit Bay, which is the largest amount from Puget Sound tributaries (Czuba et al. 2011). Shoaling in the Swinomish Channel has historically affected navigation reliability. The functionality of the channel is directly related to the condition of the navigation training structures, which have deteriorated and been modified over the past century. Recent condition surveys indicate channel depths are less than 5 feet (ft) below mean lower low water (MLLW) in the channel reach between Skagit Bay and McGlinn Island. The USACE is currently investigating alternatives to reduce the O\&M dredging demands over the next 50 years. Due to the complex vertical mixing of fresh and saline waters in Skagit Bay, the analysis employs a 3-D model to help evaluate sedimentation in the channel, which is important in accurately predicting sediment delivery off the Skagit River delta tidal flats (Ralston et al. 2013).

The Swinomish Channel navigation project was originally authorized by the Rivers and Harbors Act of 13 July 1892 to provide an 11-mile-long, $100 \mathrm{ft}$ wide, $4 \mathrm{ft}$ deep channel between Skagit Bay on the south and Padilla Bay on the north (Figure 1).

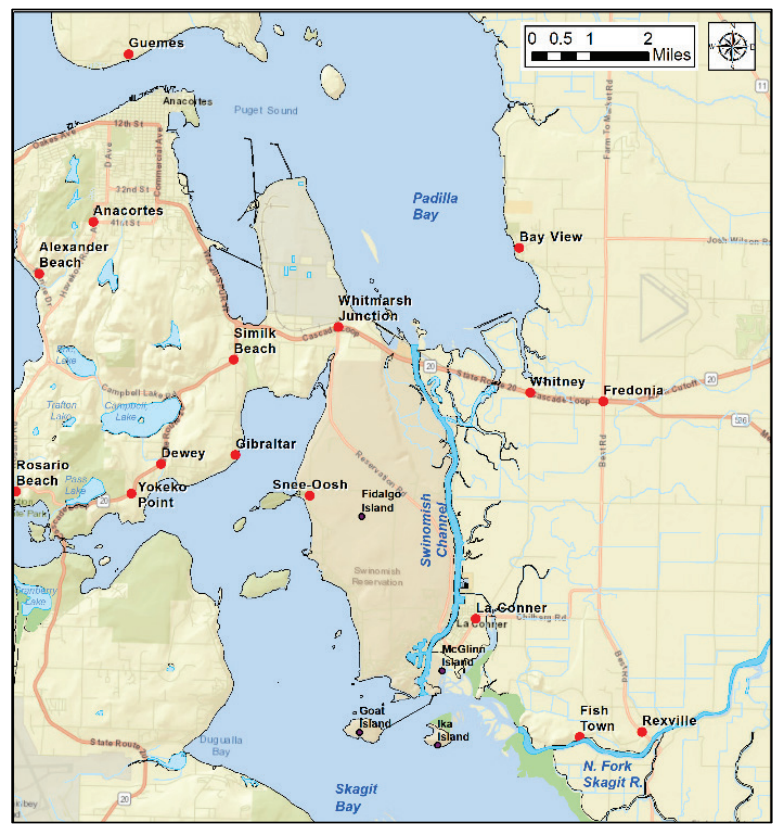

Figure 1. Swinomish Navigation Channel, Puget Sound, Washington, vicinity map. 
The Rivers and Harbor Act of 1935 modified the project to provide a channel depth of $12 \mathrm{ft}$ MLLW. The project provides the shortest and safest route for vessels traveling between northern and southern Puget Sound and represents a critical component of the U.S. Marine Transportation System, including the Alaskan fishing fleet based in Puget Sound. In Skagit Bay, four navigation training structures were constructed to confine flows and impede sediments from entering the channel from the North Fork Skagit River delta. These include a north

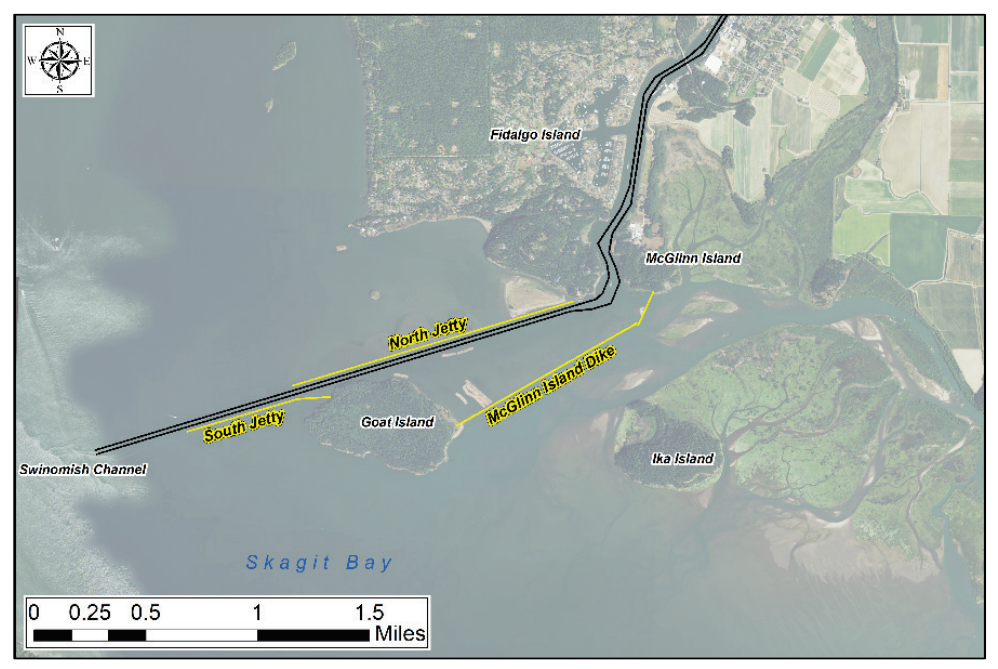

Figure 2. Approach to the Swinomish Navigation Channel from Skagit Bay. jetty extending $7,100 \mathrm{ft}$ from

Fidalgo Island, a south jetty extending 3,650 ft west of Goat Island, a 4,600 ft training dike connecting Goat Island to McGlinn Island, and a 3,500 ft dike connecting McGlinn Island to the mainland. The northern jetty was originally constructed in 1893 as a wattled timber pile dike to train flows between Fidalgo Island and Goat Island. The jetty was later reinforced with rock to a height of $+8 \mathrm{ft}$ MLLW in 1900. The south jetty extending from the west side of Goat Island to deep water in Skagit Bay was originally constructed to a height of $+8 \mathrm{ft}$ MLLW in 1908. The McGlinn Island dike was con-structed in 1910 (Figure 2).

Following construction of the two jetties and training dikes, it was observed that the influence of the sediment load from the Skagit North Fork River, coupled with the tidal head difference between Skagit Bay and Padilla Bay, presented a significant O\&M issue as fresh water carrying sediments would enter the Swinomish Channel and be transported north along the Swinomish Channel toward Padilla Bay, creating significant shoaling throughout the navigation channel. This prompted the construction of the training dike connecting Goat Island and McGlinn Island near "Hole in the Wall" in 1938 to a height of $+5 \mathrm{ft}$ MLLW. This dike quickly sustained damages from storm events and was reconstructed in 1940. In 1946, the dike crest height was raised to $+15 \mathrm{ft}$ MLLW to minimize subsidence caused from high river flows and tidal action. The south jetty was reconstructed in 1973 back to $+8 \mathrm{ft}$ MLLW. However, a $600 \mathrm{ft}$ section, which originally connected the jetty to Goat Island, was left unrepaired to facilitate fish passage (Figure 3). Presently, the south jetty has deteriorated to an elevation near mean tide level ( $+6 \mathrm{ft}$ MLLW). Additionally, the section of dike that was left unrepaired has subsided and allows a significant amount of suspended sediment into the navigation channel. Shoaling in the southern entrance of the channel from Sta. $10+00$ to $70+00$ adjacent to the south jetty has averaged 37,500 cubic yards per year (cy/year) over the last 8 years (Table 1). 


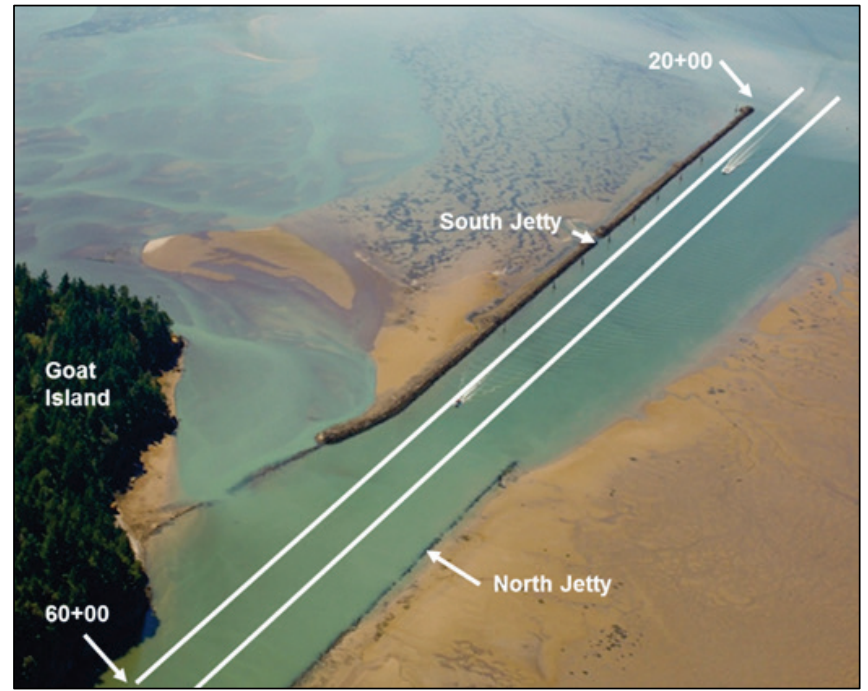

Figure 3. Unrepaired section of the South Jetty adjacent to Goat Island.

Presently the navigation channel is dredged with a clamshell bucket dredge and placed in a scow barge for transport and disposal in the Puget Sound Dredged Disposal Analysis (PSDDA) open-water disposal site in Rosario Strait (Figure 4). The site is approximately 19 miles from the southern entrance of the Swinomish Channel, and the scow must navigate through the dangerous currents of Deception Pass to reach the disposal site. In light of these challenges, there is an opportunity to bypass this sediment down-drift of the inlet, which can improve safety and minimize dredging and placement costs over the project life cycle.

APPROACH: The USACE Seattle District (NWS) recently studied the feasibility of improvements to the existing navigation structures in Skagit Bay to reduce shoaling in the federal Swinomish Navigation Channel. This included a collection of high-resolution topographic and bathymetric lidar data and development of a 3-D hydrodynamic model of the Puget Sound Basin. A suite of structural and nonstructural alternatives were analyzed using the Finite Volume Community Ocean Model (FVCOM) to compare their relative effectiveness (USACE 2017). Alternatives included (1) closing the fish gap between the south jetty and Goat Island, (2) raising the south jetty, and (3) dredging a settling basin. Dredged material placement alternatives were not specifically investigated within the scope of this study, but the model can easily be leveraged to investigate alternatives to make O\&M dredging more cost efficient. The USACE National RSM Program was a resource for studying this problem in more detail. The objective was to test the feasibility of various nearshore BUS within a 2-mile distance of the southern approach from Skagit Bay. Additionally, the six proposed placement sites were analyzed to test the fate and 
transport of sediment placed by either a bottom-dump scow or hydraulic pipeline (Figure 5). The BUS were then evaluated based on criteria developed by the multi-disciplinary team consisting of engineering, environmental, navigation, and cost experts. The engineering feasibility of each site was achieved by analyzing the fate and transport of dredged material at the potential BUS using the PTM. Metrics such as maximum Total Suspended Solids (TSS), sediment mobility, and deposition thickness were used as proxies to inform the potential impacts to environmental resources.

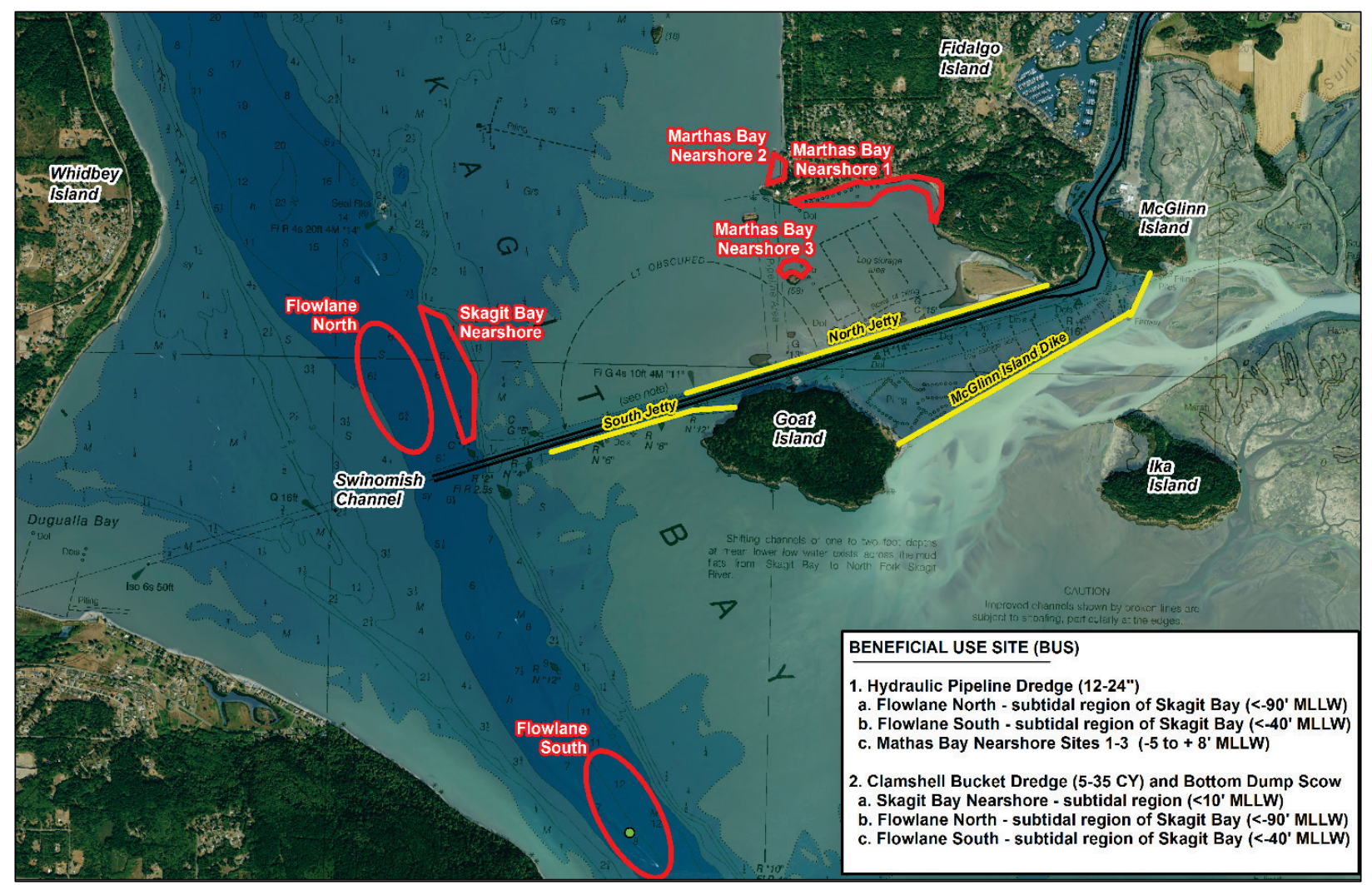

Figure 5. Six proposed BUS in Skagit Bay.

MODEL SETUP: A 3-D hydrodynamic model was developed using the FVCOM of the Skagit River estuary including Skagit Bay, the North Fork, the connection to Padilla Bay through Swinomish Channel, and the braided network associated with the South Fork was developed (Figure 4). The model includes a detailed representation of the tide flat bathymetry, river-training dikes and jetty, Swinomish Navigation Channel, and Skagit Bay. Simulation results from the model showed that tidal circulation and river plume dynamics in these shallow-water estuarine systems are affected strongly by the large intertidal zones. Strong asymmetries in tidal currents and stratification often occurred in the intertidal zones and subtidal channels. Model calibration and validation then were conducted using available short-duration current meter records from June 2005 and May 2006. Simulation results were consistent with the general understanding that the net transport of Skagit River water is out of the basin to the north through Deception Pass and the Swinomish Channel. The FVCOM model solves the 3-D momentum, continuity, temperature, salinity, and density equations in an integral form by computing fluxes between non-overlapping horizontal and triangular control volumes (Mellor and Yamada 1982; Chen et al 2003). A 30-layer sigma-stretched coordinate system was used in the vertical plane with unstructured triangular cells in the lateral plane (Khangaonkar et al. 2017). The model was validated utilizing the May 2006 
field data campaign (Figure 6), which collected water surface elevation, velocity, and salinity in Skagit Bay. Table 2 lists model calibration error statistics.

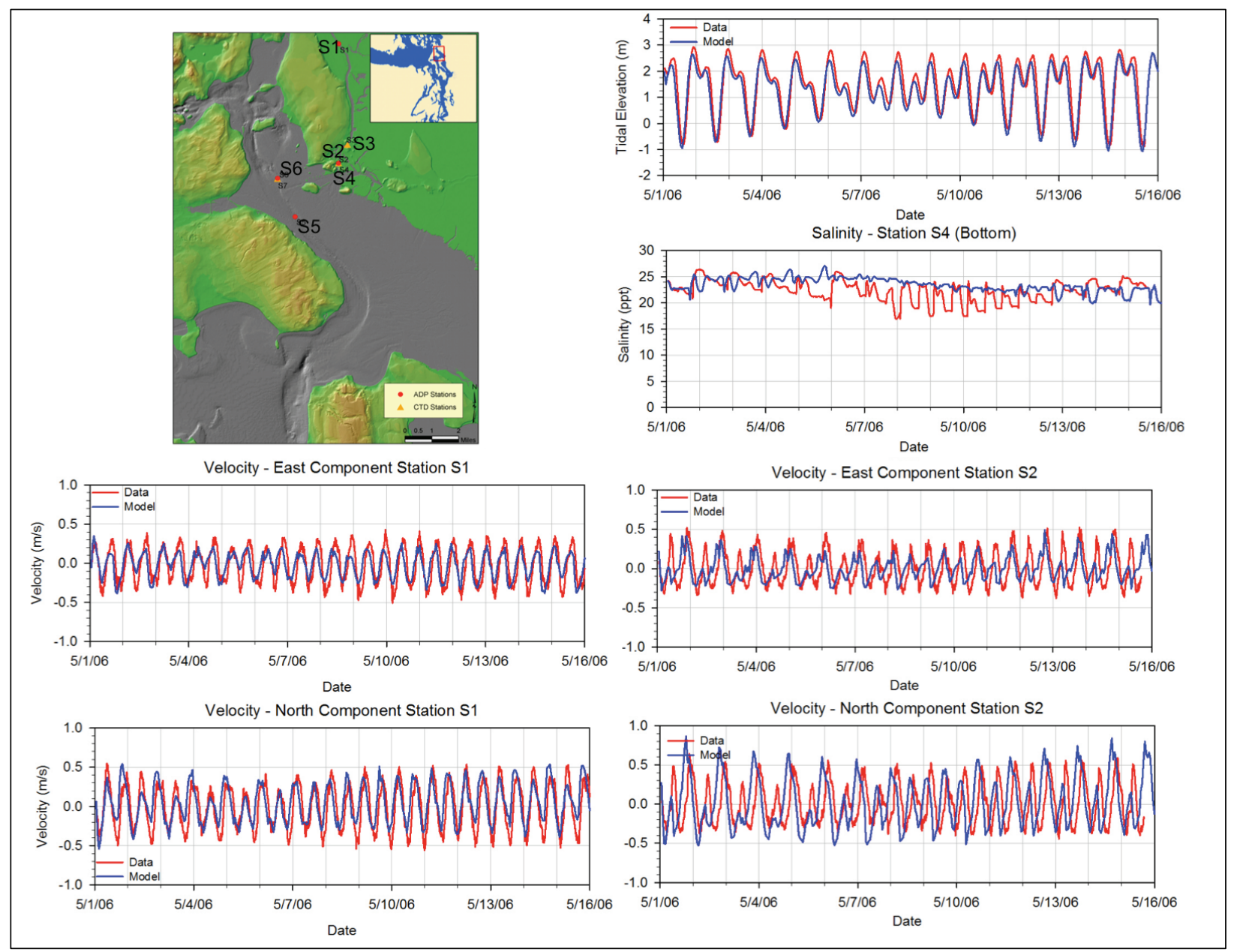

Figure 6. Comparison of observed tide, salinity, and currents in the Swinomish Channel shown as examples at stations S1, S2, and S4 during May 2006, as part of hydrodynamic model FVCOM setup and calibration (Khangaonkar et al. 2017). 


\begin{tabular}{|c|c|c|c|c|c|c|}
\hline \multirow{2}{*}{ Station } & \multicolumn{2}{|c|}{$\begin{array}{l}\text { Water Surface Level } \\
\quad(\text { meters }[\mathrm{m}])\end{array}$} & \multicolumn{2}{|c|}{$\begin{array}{l}\text { Velocity }{ }^{3} \text { (meters per second } \\
\qquad[\mathrm{m} / \mathrm{sec}])\end{array}$} & \multicolumn{2}{|c|}{$\begin{array}{l}\text { Salinity (parts per } \\
\text { thousand) }\end{array}$} \\
\hline & $\mathrm{AME}^{1}$ & $\mathrm{RMSE}^{2}$ & AME & RMSE & AME & RMSE \\
\hline S1 & - & - & $u-0.20 ; v-0.29$ & $u-0.24 ; v-0.32$ & - & - \\
\hline $\mathrm{S} 2$ & - & - & $u-0.32 ; v-0.34$ & $u-0.37 ; v-0.42$ & - & - \\
\hline S3 & - & - & - & - & 2.40 & 3.16 \\
\hline S4 & 0.31 & 0.38 & - & - & 1.73 & 2.24 \\
\hline S5 & 0.32 & 0.39 & u-0.34; v-0.22 & $u-0.42 ; v-0.26$ & - & - \\
\hline S6 & 0.26 & 0.32 & - & - & - & - \\
\hline
\end{tabular}

${ }^{1} \mathrm{AME}=$ absolute mean error; ${ }^{2} \mathrm{RMSE}=$ root mean square error; and ${ }^{3}$ velocity are the $\mathrm{u}$ and $\mathrm{v}$ components in the $\mathrm{x}$ and y (east and north) directions, respectively.

The PTM computes fate and pathways of sediments and other waterborne particulates in coastal engineering and dredging applications in a Lagrangian modeling framework (MacDonald et al. 2006; Demirbilek et al. 2008; Li et al. 2011). In general terms, a Lagrangian modeling framework is one that moves with the flow; thus, each particle is followed in time and space in the model. The PTM Lagrangian framework is one in which the sediment being modeled is discretized into a finite number of particles that are followed as they are transported by the flow. Each particle in the PTM represents a given mass of sediment (not an individual sediment particle or grain), and each particle has its own unique set of characteristics. At a minimum, a particle must be defined with certain physical properties (grain size and specific gravity), an initial position, and a flow field.

In this application, dredged material characteristics obtained from dredged material suitability testing reports from the Dredged Material Management Program were used to identify the physical sediment particle properties (USACE 2009). Over 97\% of the sediment collected was classified as sand and was considered moderately sorted. The standard deviation was utilized to specify the grain size sorting about the median grain size. In this application, $\mathrm{d}_{50}=0.375$ millimeters $(\mathrm{mm})$ $(1.4 \varphi)$, and standard deviation $(\sigma)=0.8 \varphi$ was specified. For the Swinomish project, due to the draft restrictions, a 14-inch (in.) hydraulic pipeline dredge or a 1,000 cy (765 cubic meters $\left[\mathrm{m}^{3}\right]$ ) bottom-dump scow would likely be utilized. The PTM simulates release of sediment about a point at a specified source rate, kilograms per second $(\mathrm{kg} / \mathrm{sec})$, or mass per time for dredged material discharge from a hydraulic cutter-head pipeline dredge.

For a bottom-dump scow, the PTM simulates sediment placement along a line at a specified source rate $(\mathrm{kg} / \mathrm{m} / \mathrm{sec})$, or mass per time per distance from the source line. Site-specific PTM parameters used in the simulations are listed in Table 3. The model computes the particle fate and transport over time using the current flow field output from the FVCOM model. The PTM tracks each particle's horizontal location, vertical height in the water column, and particle state (active or dead) as a function of time. An active or dead state refers to whether the particle is in motion and actively being transported, or one that has reached the seabed and is no longer suspended due to currents. 
The PTM has been successfully applied at other dispersive disposal sites within the Puget Sound region and validated against sediment vertical profiling system data (USACE 2012, 2014). TSS concentration of the dredged material and deposition on the seabed are tracked over time to determine potential impacts to environmental resources. The Skagit River delta is a very productive habitat to Endangered Species Act (ESA)listed juvenile salmon. The nearshore area is densely covered with submerged aquatic vegetation such as eelgrass (Zostera marina), which is important habitat for juvenile salmon. Additionally, threatened Puget Sound rockfish (Sebastes spp.) and bull trout (Salvelinus confluentus) fisheries also exist in the deeper portions of Skagit Bay. Due to the sensitive nature of these areas, it is critical that placement of dredged material in the proposed BUS does not significantly impact turbidity (light attenuation) or burial of existing substrate.

RESULTS: Dredged material placement was simulated at each of the six proposed BUS over a 96-hour (hr) spring tide sequence, which included eight high and eight low tides over the semi-diurnal tide cycle typical for Puget Sound. Due to the restricted depths in the Martha's Bay, nearshore BUS that are located in the intertidal region (Martha's Bay Nearshore 1, Nearshore 2, and Nearshore 3), only placement by hydraulic pipeline is feasible. The results of a Principal Component Analysis of the velocity vectors in each BUS from the FVCOM model results made it apparent that all three of the Martha's Bay nearshore sites (Nearshore 1, Nearshore 2, and Nearshore 3) were relatively non-dispersive, and capacity would quickly be utilized (Figure 7). Additionally, material placed in the Martha's Bay Nearshore Site 3 was found to have some sediment transported toward the federal Swinomish Navigation Channel.

Table 3. PTM parameters used in this application

Site specific parameters

\begin{tabular}{|l|l|}
\hline Time-step $(\mathrm{dt})$ & $10 \mathrm{sec}$ \\
\hline Grain size $(\mathrm{d} 50)$ & $0.375 \mathrm{~mm}$ \\
\hline Grain size sorting $(\sigma)$ & $0.8 \varphi$ \\
\hline
\end{tabular}

\begin{tabular}{|l|l|}
\hline Simulation duration $(\mathrm{t})$ & 96 hours \\
\hline
\end{tabular}

\begin{tabular}{|l|l|}
\hline Hydraulic pipeline & \\
\hline Source type & Point \\
\hline
\end{tabular}

\begin{tabular}{|l|l||}
\hline Horizontal Radius about source & $10 \mathrm{~m}$ \\
\hline Vertical Radius about source & $3 \mathrm{~m}$ \\
\hline Depth of release below surface & $3 \mathrm{~m}$ \\
\hline Release rate & $50 \mathrm{~kg} / \mathrm{sec}$ \\
\hline Release duration & 24 hours \\
\hline Bottom-dump barge & \\
\hline
\end{tabular}

\begin{tabular}{|l|l|}
\hline Source type & Line \\
\hline Radius of release about source & $50 \mathrm{~m}$ \\
\hline Depth of release below surface & $2 \mathrm{~m}$ \\
\hline Release rate & $5 \mathrm{~kg} / \mathrm{sec} / \mathrm{m}$ \\
\hline Release duration & $1800 \mathrm{sec}$ \\
\hline PTM parameters &
\end{tabular}

\begin{tabular}{|l|l||}
\hline Advection & 3-D \\
\hline Centroid & Rouse \\
\hline Distribution & By grain Size \\
\hline Eulerian & PTM \\
\hline Velocity profile & 2D (Logarithmic) \\
\hline Bed porosity ( $\mathrm{n})$ & 0.4 \\
\hline Bed density $(\rho)$ & $2650 \mathrm{~kg} / \mathrm{m}^{3}$ \\
\hline Min. horizontal diffusion coef.( $\left.\mathrm{E}_{\mathrm{t}, \text { min. }}\right)$ & $0.0 \mathrm{~m}^{2} / \mathrm{sec}$ \\
\hline Min. vertical diffusion coef. ( $\left.\mathrm{E}_{\mathrm{v}, \text { min. }}\right)$ & $0.0 \mathrm{~m}^{2} / \mathrm{sec}$ \\
\hline $\begin{array}{l}\text { Turbulent diffusion scalar (horizontal) } \\
\text { (KEt) }\end{array}$ & 0.25 \\
\hline Turbulent diffusion scalar (vertical) $\left(\mathrm{K}_{\mathrm{Ev}}\right)$ & 0.00859 \\
\hline
\end{tabular}


Computational scenarios for the remaining three BUS (Flowlane North, Flowlane South, and the Skagit Bay Nearshore) showed better potential. Hydraulic or bottom-dump scow placement is potentially feasible at each of these sites. Hydraulic placement of dredged material in the flowlane has been successfully utilized as an efficient and cost-effective means to maintain local ports in Tokeland and Ilwaco, WA, on the southwest Washington Pacific coast (Arden and Kraus 2010). Fast tidal currents in the flowlane sites disperse material quickly, which serves as a process-based solution for managing sediment while avoiding the typical pitfalls such as loss of capacity over time at a non-dispersive (deep water) dredged material placement site. In each site (Flowlane North, Flowlane South, and Skagit Bay), the maximum velocity is approximately $2 \mathrm{knots}(1 \mathrm{~m} / \mathrm{sec})$ during a spring tide event. The pump distance from the channel shoaling area to the flowlane placement site is 1.5 to 2 miles (2.3 to 3 kilometers $[\mathrm{km}])$.

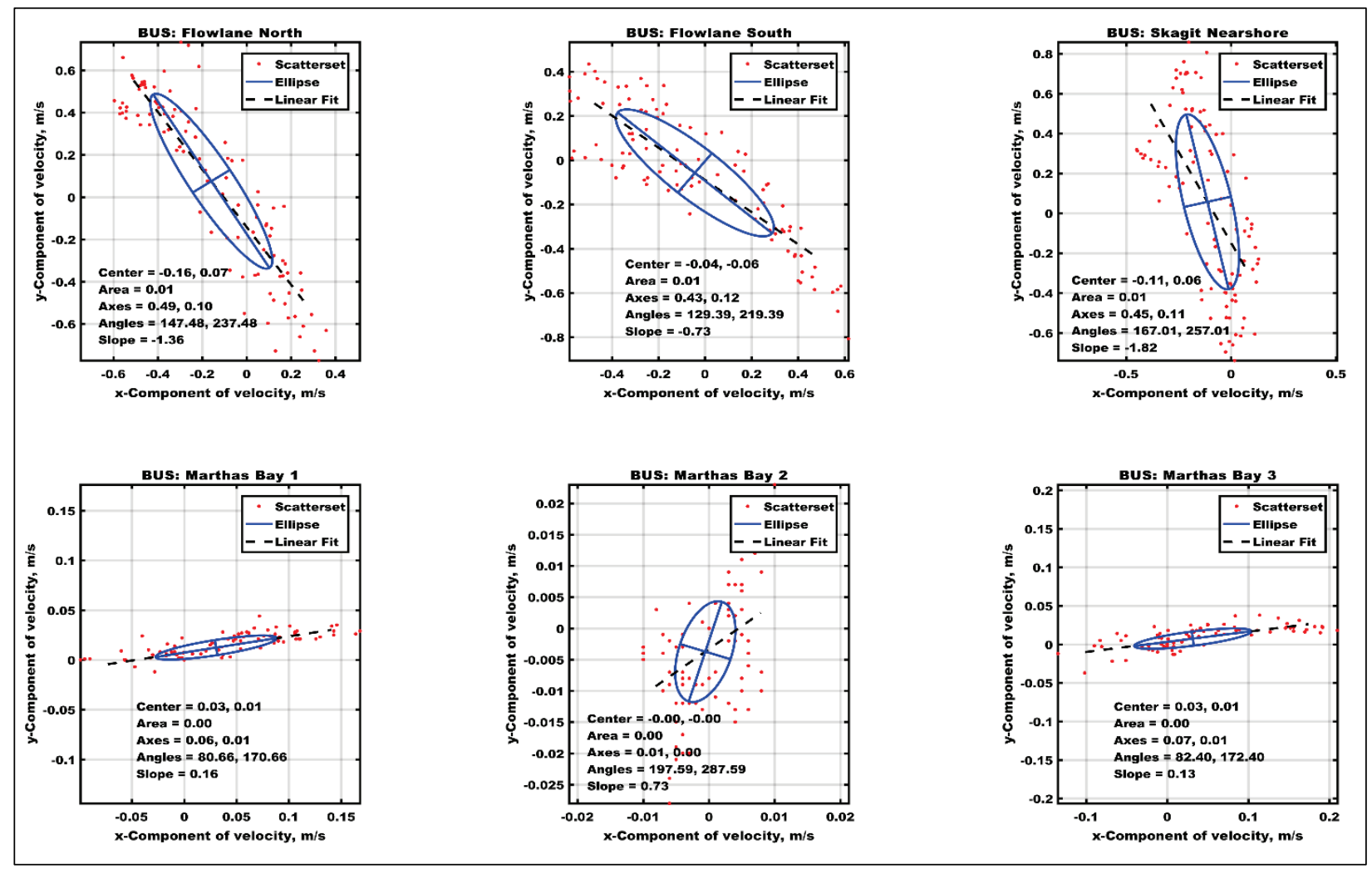

Figure 7. Principal Component Analysis of velocity vectors in each BUS from FVCOM model results.

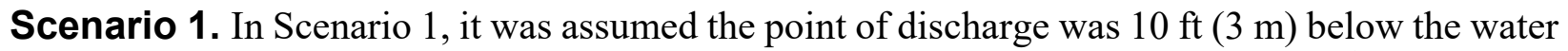
surface at the Flowlane North placement site. A production rate of $125 \mathrm{cy} / \mathrm{hr}\left(95 \mathrm{~m}^{3} / \mathrm{hr}\right)$ for a 14 in. (35.5 centimeters $[\mathrm{cm}])$ pipeline dredge was used based on observed data at the federal O\&M dredging of the Snohomish River in Everett, WA. This amounts to a release rate of $50 \mathrm{~kg} / \mathrm{sec}(110$ pounds [lb]/sec) over a duration of $24 \mathrm{hr}$, assuming a bulk density of sand of $110 \mathrm{lb}$ per cubic foot $\left(\mathrm{lb} / \mathrm{ft}^{3}\left[1,762 \mathrm{~kg} / \mathrm{m}^{3}\right]\right)$ for a total of $3,000 \mathrm{cy}\left(2,300 \mathrm{~m}^{3}\right)$. The PTM simulations indicated sediments placed in the Flowlane North site have a maximum TSS concentration of $0.04 \mathrm{lb} / \mathrm{ft}^{3}(626$ milligrams $[\mathrm{mg}]$ per liter $[\mathrm{mg} / \mathrm{L}])$ at the point of discharge, and the plume diffuses to $0.0003 \mathrm{lb} / \mathrm{ft}^{3}$ $(5 \mathrm{mg} / \mathrm{L})$ within a distance of 1.1 mile $(1.8 \mathrm{~km})$. TSS was calculated by the PTM to not exceed $0.0003 \mathrm{lb} / \mathrm{ft}^{3}(5 \mathrm{mg} / \mathrm{L})$ in any of the mapped eelgrass beds (Table 4). This suggests placement in the flowlane sites would have minimal impact to TSS and light attenuation within the eelgrass habitat. Figure 8 shows the transport pathways (i.e., orange lines) and maximum total suspended 
solids (TSS) (i.e., contours) during the $96 \mathrm{hr}$ simulation period. Sensitive eelgrass areas are denoted by the green polygons, and rockfish habitat by the magenta polygons. Similarly, deposition within the rockfish habitat was computed at a maximum of 1 in. $(2.5 \mathrm{~cm})$ over the simulation period (Figure 9). The area of deposition above 0.8 in. $(2.0 \mathrm{~cm})$ in the rockfish habitat was computed to be 1.2 acres $(0.5$ hectares). The model results indicated placement in this area may modify the substrate, as the rockfish habitat area north of the placement site acts as a natural depositional area.

\begin{tabular}{|l|l|l|l||}
\hline \multicolumn{4}{||l}{ Table 4. PTM results for the three scenarios tested. } \\
\hline & $\begin{array}{l}\text { Flowlane } \\
\text { North }\end{array}$ & $\begin{array}{l}\text { Flowlane } \\
\text { South }\end{array}$ & $\begin{array}{l}\text { Skagit Bay } \\
\text { Nearshore }\end{array}$ \\
\hline Type of Placement & Hydraulic & Hydraulic & Barge \\
\hline Maximum TSS (mg/L) & 626 & 702 & 755 \\
\hline $\begin{array}{l}\text { Maximum plume distance } \\
\text { to } 5 \mathrm{mg} / \mathrm{L}(\mathrm{km})\end{array}$ & $1.8 \mathrm{~km} \mathrm{NW}$ & $2.5 \mathrm{~km} \mathrm{SE}$ & $1.7 \mathrm{~km} \mathrm{~S}$ \\
\hline Max deposition (mm) & 25.2 & 22.8 & 405 \\
\hline $\begin{array}{l}\text { TSS above } 5 \mathrm{mg} / \mathrm{L} \text { in } \\
\text { mapped eelgrass } \\
\text { (hectares) }\end{array}$ & 0 & 17.1 & 28.0 \\
\hline $\begin{array}{l}\text { Deposition above } 2 \mathrm{~cm} \text { in } \\
\text { Rockfish habitat } \\
\text { (hectares) }\end{array}$ & 0.5 & 0 & 0 \\
\hline \hline
\end{tabular}

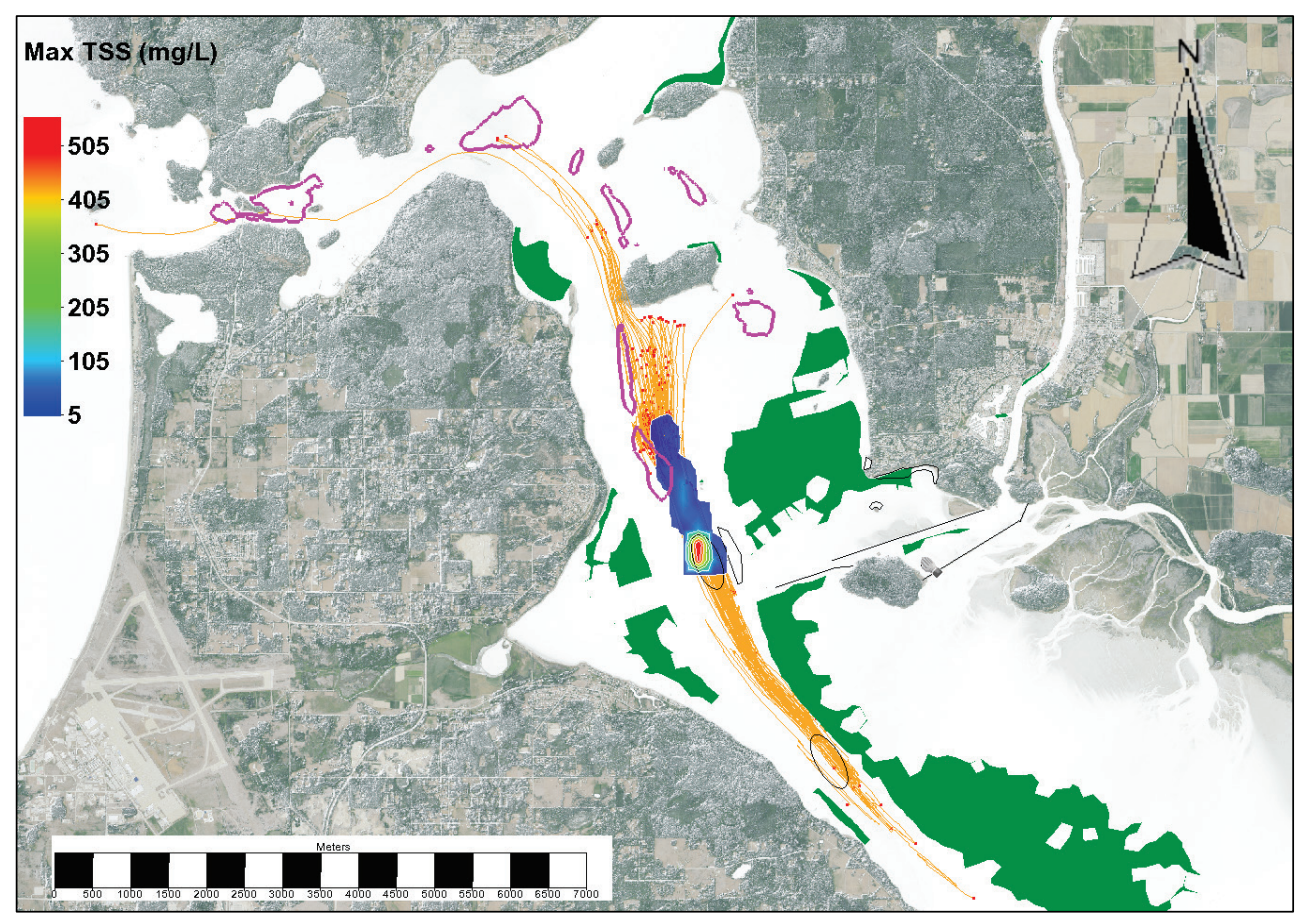

Figure 8. Scenario 1, Flowlane North hydraulic placement. Maximum TSS (mg/L) over simulation period. (Magenta polygons denote rockfish habitat; orange lines denote transport pathways; contours denote maximum TSS). 


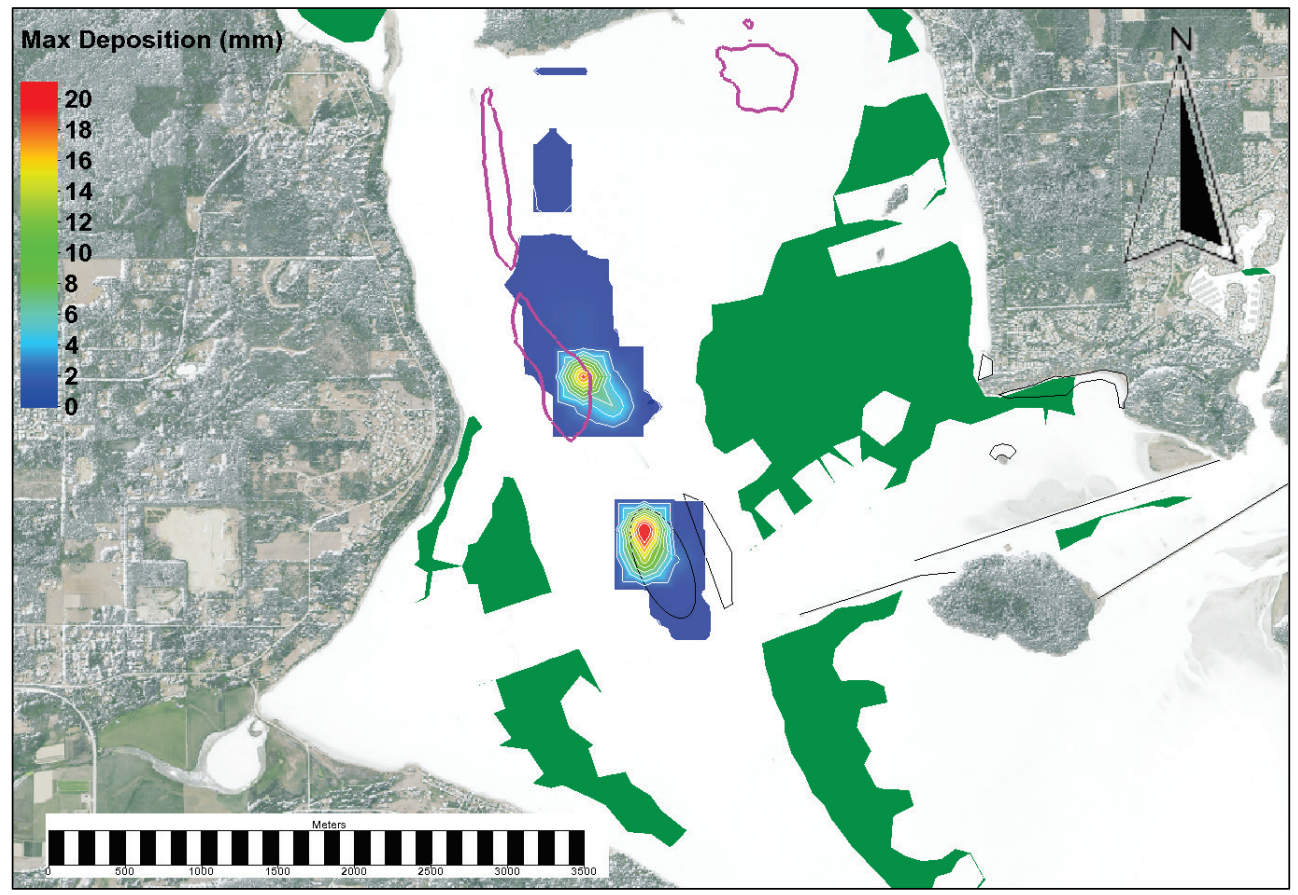

Figure 9. Scenario 1, Flowlane North hydraulic placement. Maximum deposition $(\mathrm{mm})$ over the simulation period within the rockfish habitat (magenta polygons).

Scenario 2. In Scenario 2, dredged material was similarly hydraulically discharged into the Flowlane South placement site. The maximum plume of TSS above $5 \mathrm{mg} / \mathrm{L}$ extends southeast along the direction of net transport approximately 1.6 miles $(2.5 \mathrm{~km})$. The plume with TSS greater than $0.0003 \mathrm{lb} / \mathrm{ft}^{3}(5 \mathrm{mg} / \mathrm{L})$ was shown to overlap 42.3 acres $(17.1$ hectares $)$ of the mapped eelgrass (Figure 10). However, there was not any deposition found above $0.8 \mathrm{in} .(2 \mathrm{~cm})$ in the mapped rockfish habitat (Figure 11). 


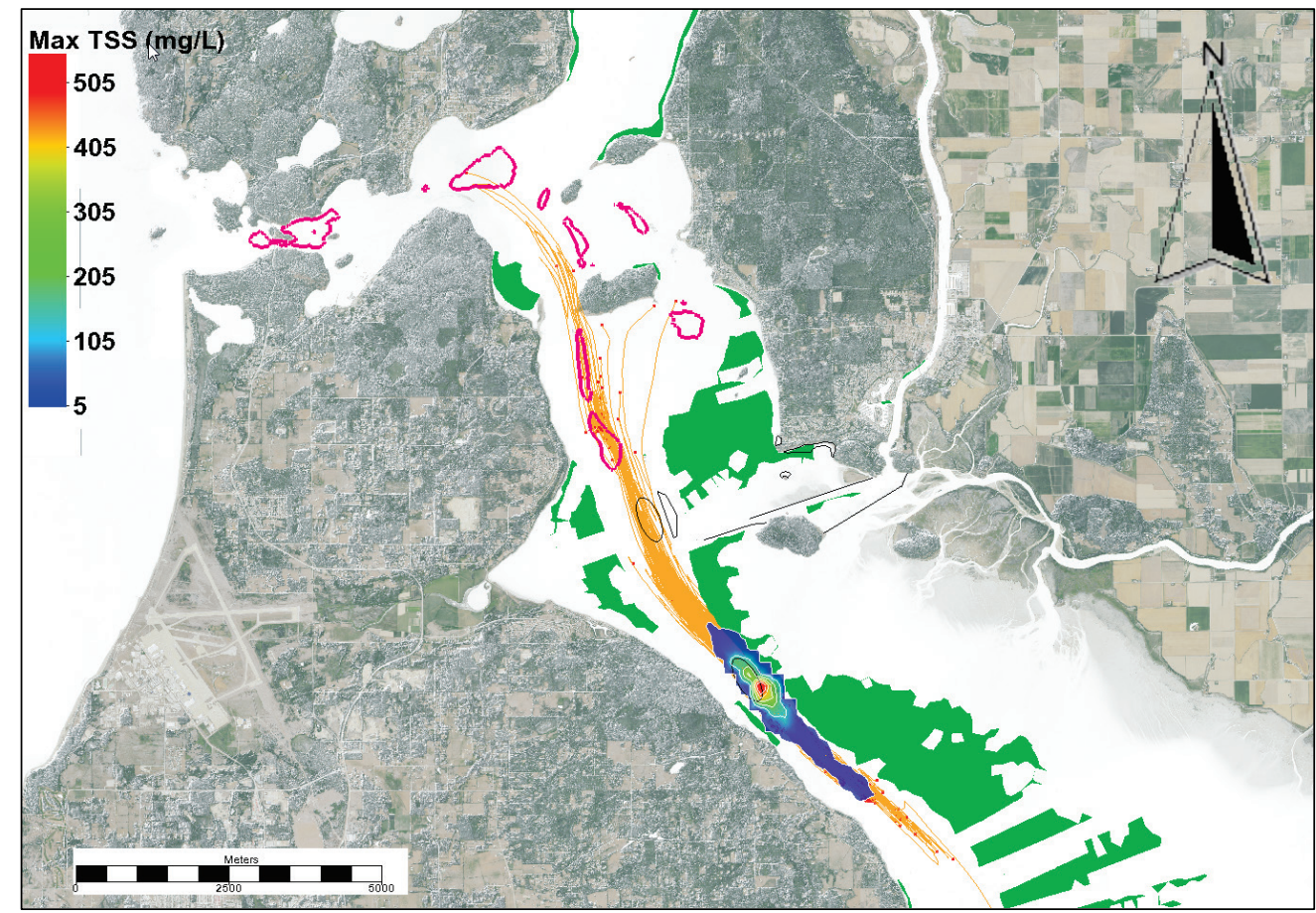

Figure 10. Scenario 2, Flowlane South hydraulic placement. Maximum TSS (mg/L) over simulation period. (Magenta polygons denote rockfish habitat; orange lines denote transport pathways; contours denote maximum TSS.)

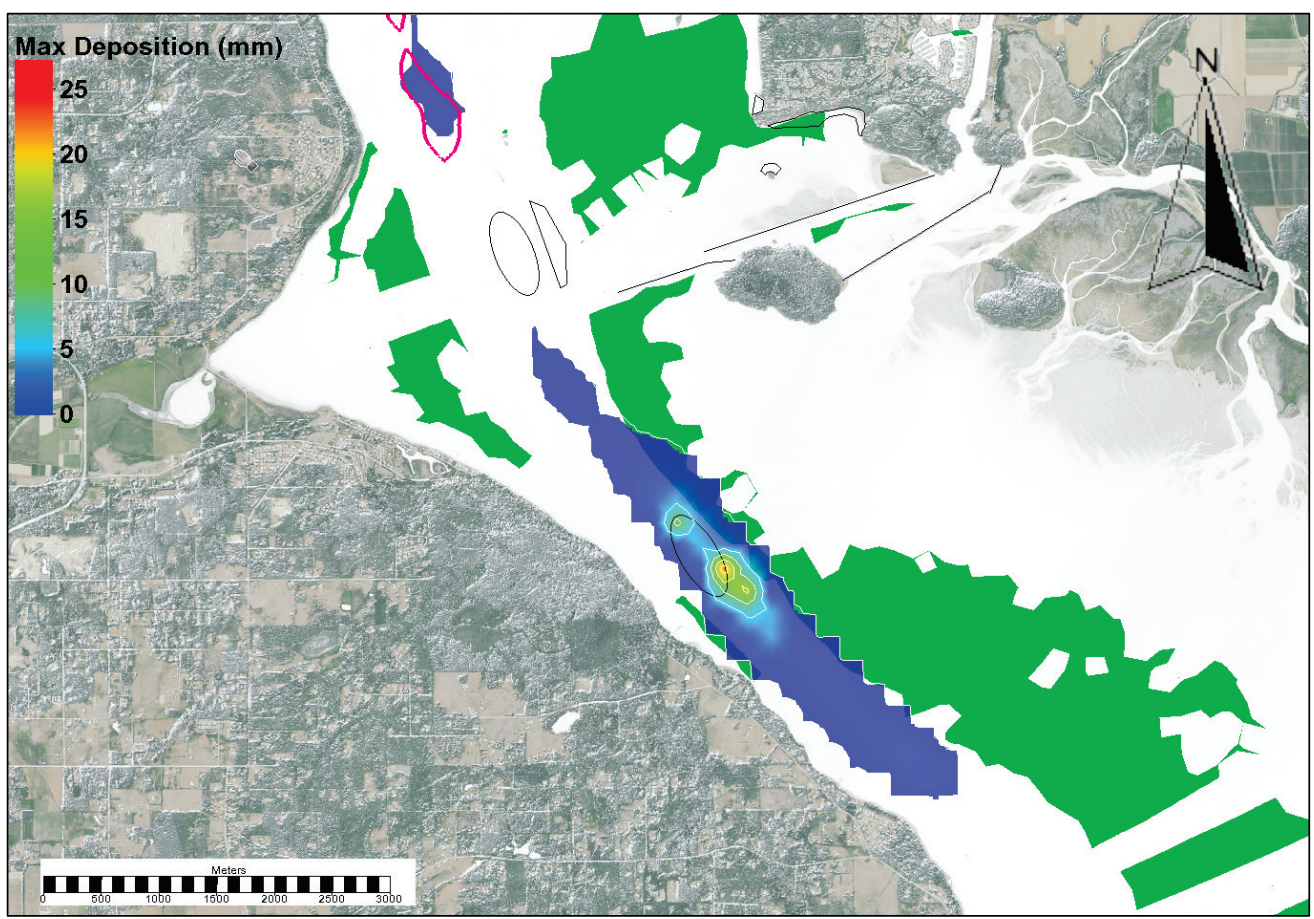

Figure 11. Scenario 2, Flowlane South hydraulic placement. Maximum deposition $(\mathrm{mm})$ over the simulation period within the rockfish habitat (magenta polygons). 
Scenario 3. In Scenario 3, placement of dredged material from a bottom-dump scow barge was simulated at the Skagit Bay nearshore site. The intent of this site is to provide a local placement area and potentially expand the area suitable for eelgrass habitat over time. Bottom-dump placement was simulated using a source rate applied over a $50 \mathrm{~m}$ radius about the source. Three separate dumps lasting 1,800 sec each were simulated over the $96 \mathrm{hr}$ simulation period. The maximum plume of TSS above $0.0003 \mathrm{lb} / \mathrm{ft}^{3}(5 \mathrm{mg} / \mathrm{L})$ extends south approximately 1.1 miles $(1.7 \mathrm{~km})$. The plume with TSS greater than $0.0003 \mathrm{lb} / \mathrm{ft}^{3}(5 \mathrm{mg} / \mathrm{L})$ was shown to overlap 69.2 acres (28.0 hectares) of the mapped eelgrass (Figure 12). However, there was not any deposition found above 0.8 in. $(2 \mathrm{~cm})$ in the mapped rockfish habitat (Figure 13).

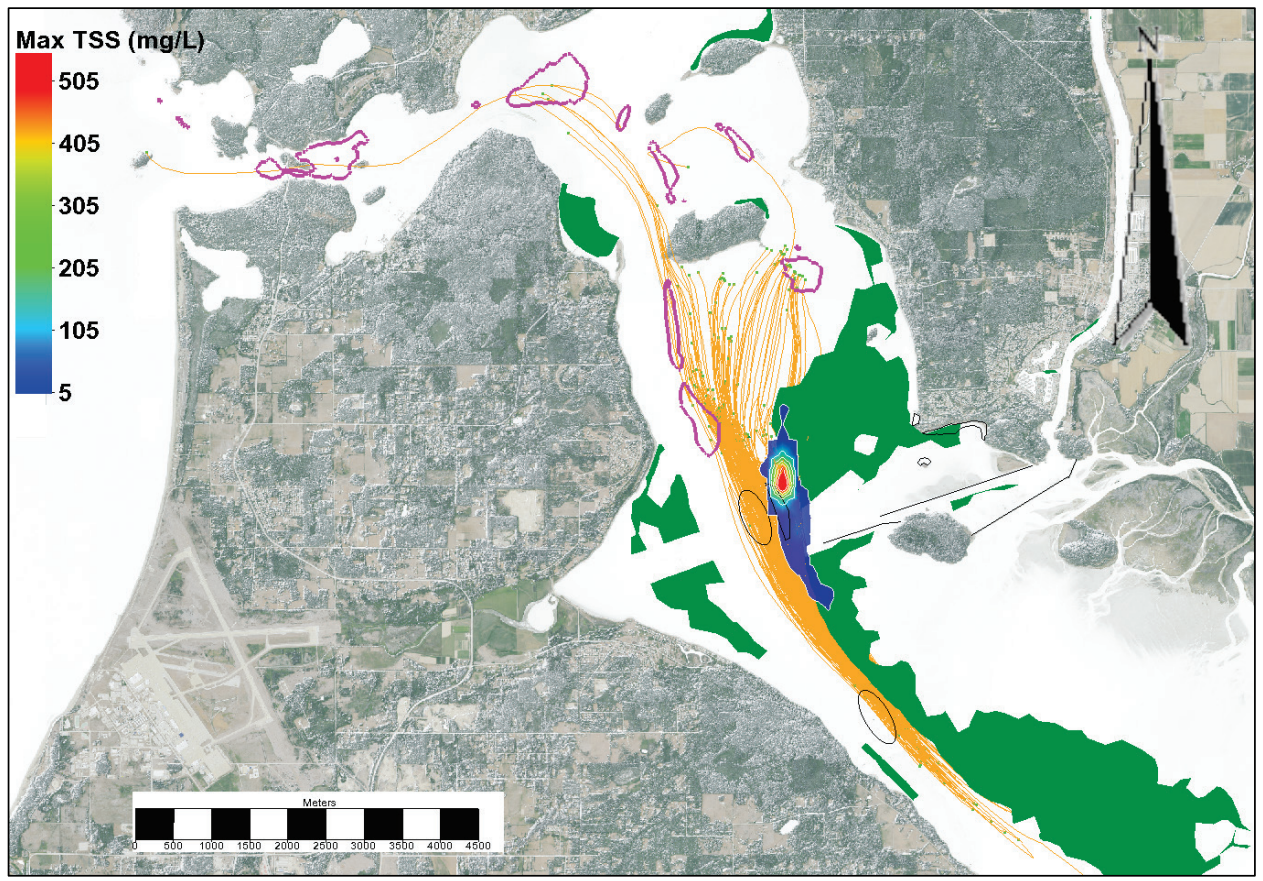

Figure 12. Scenario 3, Skagit Bay Nearshore bottom dump barge placement. Maximum TSS (mg/L) over simulation period. (Magenta polygons denote rockfish habitat; orange lines denote transport pathways; contours denote maximum TSS.) 


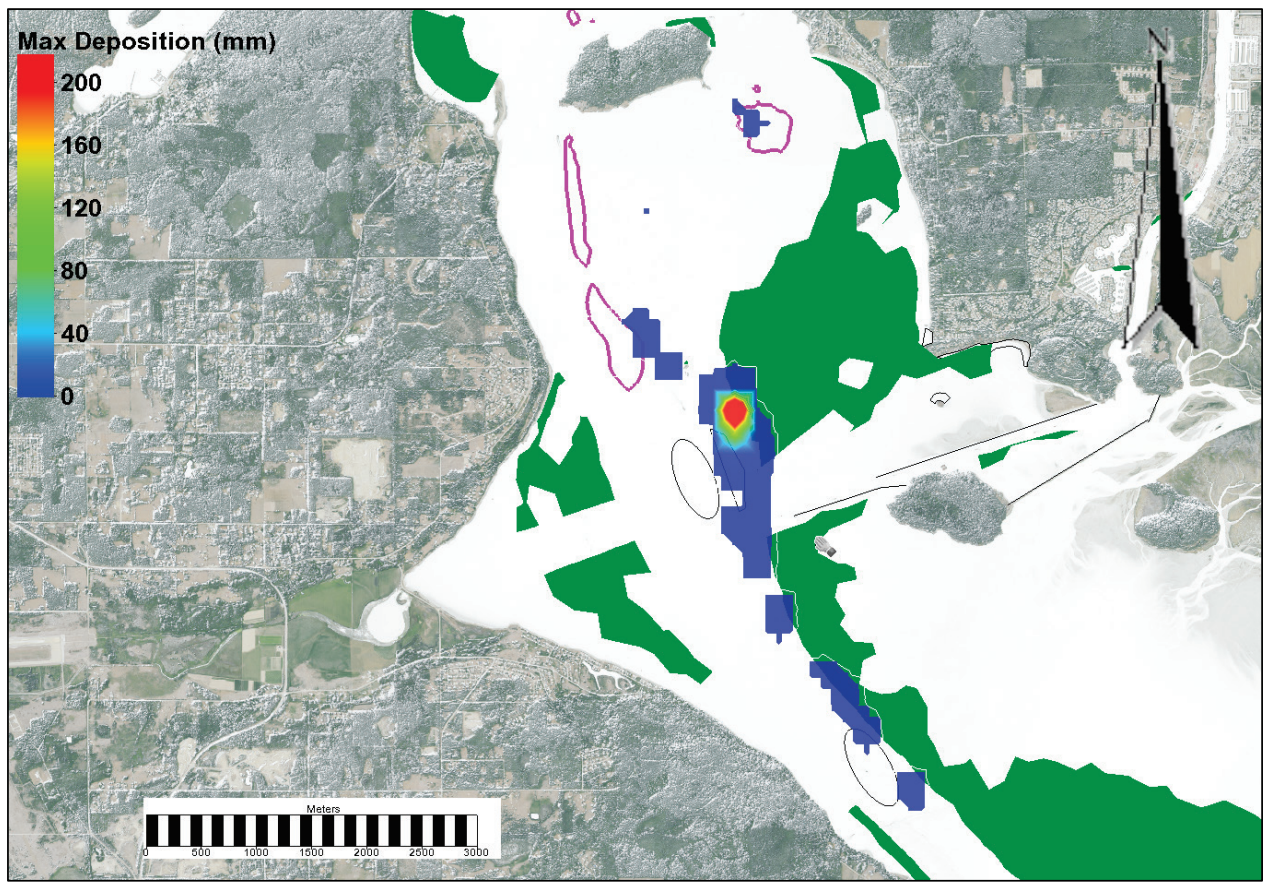

Figure 13. Scenario 3. Skagit Bay Nearshore bottom dump barge placement. Maximum deposition $(\mathrm{mm})$ over the simulation period within the rockfish habitat (magenta polygons).

CONCLUSIONS: The PTM was employed to investigate the use of six proposed nearshore placement sites within 2 miles $(3.2 \mathrm{~km})$ of the southern approach to the Swinomish Navigation Channel. Three of the sites within the shallow nearshore region of Martha's Bay were rejected due to the non-dispersive nature and likelihood of sediments reentering the federal Swinomish Navigation Channel. Three of the sites showed more potential: two sites located in the Flowlanes to the North and South of the inlet and one on the flanks of the Skagit River delta north of the inlet. The two Flowlane sites were found to be the most dispersive, resulting in the greatest transport rate and distance traveled. Due to the presence of critical habitat for rockfish located in a deep region of Skagit Bay just north of the Flowlane North site, the PTM was used to quantify the amount of deposition resulting from dredged material placed at each site. Neither site was found to result in a significant amount of deposition within these habitat regions. However, due to the proximity of the Flowlane North site to rockfish habitat, some deposition above 0.8 in. $(2 \mathrm{~cm})$ was found. Additionally, due to submerged aquatic vegetation, namely eelgrass (an import habitat for ESAlisted juvenile salmonids), the PTM was used to calculate TSS from the placement plume as a proxy to determine impact to light attenuation on the eelgrass beds. The simulations indicate that placement in the Flowlane South and Skagit Bay Nearshore sites potentially have the greatest impact. However, more research regarding what levels of TSS may be acceptable to eelgrass during placement should be performed prior to ruling these sites out.

ADDITIONAL INFORMATION: This Regional Sediment Management Technical Note (RSMTN) was prepared by David R. Michalsen of the USACE NWS as part of the RSM initiative funded by the USACE National RSM Program. Editorial revisions were provided by Scott H. Brown, NWS. Additional information pertaining to the RSM Program can be found at the RSM website http://rsm.usace.army.mil. 
Questions regarding this RSM-TN may be addressed to the following:

David R. Michalsen

NWS RSM POC

David.R.Michalsen@usace.army.mil

Katherine E. Brutsche

USACE National RSM Program Manager

Katherine.E.Brutsche@usace.army.mil

This ERDC/TN RSM-19-6 should be cited as follows:

Michalsen, D. R., and S. H. Brown. 2019. Feasibility of Nearshore Placement near the Swinomish Navigation Channel: Puget Sound, Washington. ERDC/TN RSM-19-6. Vicksburg, MS: U.S. Army Engineer Research and Development Center. http://dx.doi.org/10.21079/11681/33885

\section{REFERENCES}

Arden, H. T., and N. C. Kraus. 2010. Proactive Strategy for "Dredge-Ready" Operation and Maintenance at LowUse Navigation Projects. ERDC/CHL CHETN-IV-75. Vicksburg, MS: U.S. Army Engineer Research and Development Center. http://hdl.handle.net/11681/2005

Chen, C., H. Lui, and R. C. Beardsley. 2003. "An Unstructured, Finite-Volume, Three-Dimensional, Primitive Equation Ocean Model: Application to Coastal Ocean and Estuaries." J. Atmos. Ocean Technol. 20: 159-186.

Czuba, J. A., C. S. Magirl, C. R. Czuba, E. E. Grossman, C. A. Curran, A. S. Gendaszek, and R. S. Dinicola. 2011. Sediment Load from Major Rivers into Puget Sound and Its Adjacent Waters. U.S. Geological Survey Fact Sheet 2011-3083. https://pubs.usgs.gov/fs/2011/3083/

Demirbilek, Z., K. J. Connell, N. J. MacDonald, and A. K. Zundel. 2008. Particle Tracking Model in the SMS 10: IV. Link to Coastal Modeling System. ERDC/CHL CHETN-IV-71. Vicksburg, MS: U.S. Army Engineer Research and Development Center. http://hdl.handle.net/11681/2004

Khangaonkar T. P., H. Nugrah, S. Hinton, D. R. Michalsen, and S. H. Brown. 2017. "Sediment Transport into the Swinomish Navigation Channel, Puget Sound: Habitat Restoration Versus Navigation Maintenance Needs." Journal of Marine Science and Engineering 5(2): Article No. 19. https://doi.org/10.3390/jmse5020019

Li, H., L. Lin, and M. E. Brown. 2011. Applying Particle Tracking Model in the Coastal Modeling System. ERDC/CHL CHETN-IV-78. Vicksburg, MS: U.S. Army Engineer Research and Development Center. http://hdl.handle.net/11681/2014

MacDonald, N. J., Z. Demirbilek, J. Z. Gailani, T. C. Lackey, and S. J. Smith. 2006. PTM: Particle Tracking Model; Report 1: Model Theory, Implementation, and Example Applications. ERDC/CHL-TR-06-20. Vicksburg, MS: U.S. Army Engineer Research and Development Center. http://hdl.handle.net/11681/7695

Mellor, G. L., and T. Yamada. 1982. "Development of a Turbulence Closure Model for Geophysical Fluid Problems." Rev. Geophys. 20: 851-875.

Ralston, D. K., W. R. Geyer, P. A. Traykovski, N. and J. Nidzieko. 2013. "Effects of Estuarine and Fluvial Processes on Sediment Transport over Deltaic Tidal Flats." Continental Shelf Research. 60(Supplement): S40S57. DOI: 10.1016/j.csr.2012.02.004

U.S. Army Corps of Engineers (USACE). 2009. Determination on the Suitability of Proposed Dredged Material Tested for the Federal Swinomish Channel Navigation Dredging Project. Memorandum for Record. 11 December 2009. Seattle, WA: U.S. Army Engineer District, Seattle.

USACE. 2012. Dispersive Disposal Site Fate and Transport Analysis for Puget Sound, Washington. Dredged Material Management Program. September 2012. Seattle, WA: U.S. Army Engineer District, Seattle. 
USACE. 2014. Anderson-Ketron PSDDA Disposal Site Fate and Transport Modeling. Dredged Material Management Program. September 2014. Seattle, WA: U.S. Army Engineer District, Seattle.

USACE. 2017. Swinomish Federal Navigation Channel: Evaluation of Goat Island (South) Jetty Functionality. Engineering Analysis. October 2017. Seattle, WA: U.S. Army Engineer District, Seattle.

NOTE: The contents of this technical note are not to be used for advertising, publication, or promotional purposes. Citation of trade names does not constitute an official endorsement or approval of the use of such products. 